\title{
Human Trafficking as a Social Practice
}

\author{
Introduction
}

In order to be able to discuss the legal definition of trafficking, we need to acquaint ourselves with the characteristics of the phenomenon. Consequently, before proceeding to an analysis of the legal definition of trafficking, the nature of the crime is discussed in more detail. First, factors that are thought to drive trafficking, i.e., so-called push and pull factors, are touched upon. Then, different perspectives of looking at trafficking, e.g., migration and gender, are addressed. This chapter is intended to function as a backdrop for the following analyses of the international definition of trafficking and the national provisions that this definition has inspired.

\section{Trafficking: An Overview}

Human trafficking constitutes a highly lucrative business. People all over the globe are being sold, bought, and maltreated against their will. Various organizations give different estimates as to the scope of trafficking. The lack of exact statistics has prompted some states to act in accordance with the saying out of sight out of mind, i.e., to deny that they have a trafficking problem. It has been said that it is only by understanding the depth and scope of human trafficking that we can adequately address the issue of how to counter it. At the same time not much knowledge on the crime has been attained, which in effect has made anti-trafficking efforts inadequate and disjointed. ${ }^{1}$ Although trafficking statistics will never be entirely precise due to the phenomenon's clandestine nature, other factors can be used as indicators. The statistics of countries of origin concerning emigration can, e.g., be used as an indicator of trafficking. According to Ukrainian emigration statistics, during a ten-year period beginning with the demise of communism some 400,000 women had migrated from Ukraine. ${ }^{2}$ Another indicator might be found in national polls. In such polls conducted in Poland in 2001 and 2005, every fifth woman responded that she would not hesitate to accept

1 "Global Report on Trafficking in Persons", UnOdC, 2009, p. 2.

2 O. Malynovska, "International Migration in Contemporary Ukraine: Trends and Policy", Global Migration Perspectives, no. 14, Global Commission on Migration (GCIM), 2004, p. 31.

(C) KONINKLIJKE BRILL NV, LEIDEN, 2015 | DOI 10.1163/9789004281073_004

This is an open access chapter distributed under the terms of the prevailing CC-BY-NC License at the time of publication. 
a dubious job offer abroad, while every fourth woman claimed that she would accept a 'normal' job offer without examining its legitimacy. ${ }^{3}$

Though states view trafficking as a crime that affects the victim and, especially when an organized crime group is involved, the state's security and immigration restrictions, ${ }^{4}$ there are other areas that need to be recognized. The trade can assume various forms such as forced labour, illegal adoptions, and even human organ and tissue removal. In this context, it is also important to mention that trafficking is not only a transnational crime but that so-called internal trafficking is also common in many countries. Typically, people living in poorer rural areas or minority Diasporas are sent to richer regions of the country. However, on both the international and national levels focus has mostly been on transnational trafficking.

Trafficking in human beings is not 'just' a crime. It is a practice that affects entire societies or rather the very fabric of democratic societies. It undermines the very foundations of liberal democracies by violating principles of integrity and human dignity. ${ }^{5}$ If not a direct purpose, the consequence of trafficking is that human rights are violated. In truth, the human dignity of the victims is being infringed upon. Human trafficking also leads to loss of human capital, drives organized crime, fuels political corruption, and causes the spread of HIV and other venereal diseases.

\section{Trafficking in Human Beings after the Demise of Communism}

After the end of the Cold War, the post-communist states have emerged as one of the main regions of origin for victims of trafficking. There are so many Russian-speaking victims of trafficking in the global sex industry that they have collectively been dubbed 'Natashas'. ${ }^{6}$

Although the demise of communism in Central and Eastern Europe opened a door to or at least a Pushkinian window on Western Europe, the long-term

3 "Wiedza i opinie o handlu kobietami. Komunikat z badań", Centrum badania opinii społecznej, Warszawa, 2001, http://www.cbos.pl/SPISKOM.POL/2001/K_124_01.PDF, (accessed 19 May 2014) and "Polacy o zjawisku handlu kobietami. Komunikat z badań", Centrum badania opinii społecznej, Warszawa, 2005, http://www.cbos.pl/SPISKOM.POL/2005/K_008_05 .PDF, (accessed 19 May 2014).

4 A. Gallagher, "Human Rights and the New un Protocols on Trafficking and Migrant Smuggling: A Preliminary Analysis", Human Rights Quarterly, vol. 23, 2001, p. 976.

5 T. Obokota, Trafficking in Human Beings from a Human Rights Perspective. Towards a Holistic Approach, Leiden, Martinus Nijhoff Publishers, 2006, p. 9

6 See, e.g., V. Malarek, The Trade in Natashas. Inside the New Global Sex Trade, New York, Arcade Publishing, 2004. 
processes of economic, political, and legal transformation are not yet at their end. In some cases, we might have to accept the idea that some states are just not heading for democracy and market economy.

Economically, many of the countries in this region continue to fall behind their Western neighbours while political instability and corruption hinder further reforms. Poverty and unemployment rates, especially among women, are still exceedingly high. This development is termed the feminization of poverty.

Political instability, deficient law enforcement, and lacking border control mechanisms in the Eastern European states (this concerns primarily the countries of the old Soviet Union including the cis states) created the perfect environment for criminal activities. ${ }^{7}$ These factors, together with the opening up of borders to Western Europe and the process of globalization, particularly advancement in communication and transportation, have led to an increase in trafficking in human beings. Restrictive immigration policies in the destination countries combined with the fact that there are few legitimate job offers in Western Europe for foreign nationals with elementary education and no language skills have created optimal conditions for traffickers and human smugglers to capitalize on the dreams and false hopes of the less fortunate ones.

Where trafficking is concerned, there is also the matter of political and financial corruption. Corruption makes organized crime very difficult to counter as criminals may bribe or even threaten judges and law enforcement officials. Sometimes, high ranking officials are involved in illicit activities. ${ }^{8}$ In Ukraine, e.g., convicted traffickers seldom serve time in jail. ${ }^{9}$

Trafficking in human beings as a social phenomenon is usually explained in terms of specific push factors in the countries of origin and pull factors in the countries of destination. In the following, these factors will be described in more detail.

\section{Push and Pull Factors}

Trafficking as a social practice is often explained in terms of factors of push and pull. The push factors, on the one hand, are connected to the concept of

7 L.I. Shelley, "Russia's Efforts to Combat Human Trafficking: Efficient Crime Groups versus Irresolute Societies and Uncoordinated States" in W.A. Pridemore (edt.), Ruling Russia. Law, Crime and Justice in a Changing Society, Lanham, Rowman \& Littlefield Publishers, 2005, p. 181.

8 During 2010, several high ranking officials in Russia including a police colonel and a senior military officer were exposed for their involvement in trafficking. See "Russia", TIP Report, 2011.

9 See, e.g., "Ukraine", TIP Reports from 2009, 2010 and 2011. 
supply, i.e., the supply of victims depends on the existence of specific push factors. These are found in the countries of origin. Pull factors, on the other hand, are to be found in the countries of destination. They include demand but also other factors that influence the decisions of migrants and traffickers. The push factors can be divided into socioeconomic, sociocultural, political, and legal factors (and sometimes also environmental factors). ${ }^{10}$

During the 199os, privatization, the aim of which was to transform the centralized planned economies of Eastern and Central Europe into market economies, commenced. The first thing on the agenda was to introduce and institutionalize the concept of private ownership, i.e., to adopt laws and create institutions, the purpose of which would be to establish and protect property rights of both individuals and legal entities. In the communist countries, politics and economy were intertwined. The resources were therefore not utilized effectively. Unsuccessful enterprises, e.g., were rarely liquidated. ${ }^{11}$ As a result of privatization, many people, mostly women, ${ }^{12}$ lost their jobs.

Transition also led to a collapse of the old social safety nets, leaving many people impoverished. In that context, many were forced to consider more unconventional methods of earning a living including prostitution. An interesting fact is that Russian women victims of trafficking frequently differ from trafficking victims from other countries in that they often have secondary and even post-secondary education. ${ }^{13}$

Sociocultural factors are closely intertwined with socioeconomic factors. As has been mentioned above, the privatization process in the former communist states led to high unemployment rates, especially among women and people living in rural areas. Even in richer countries like Poland, unemployment rates are significantly higher among women. ${ }^{14}$ This is also true for certain minorities and is a result of discrimination based on ethnic

\footnotetext{
10 See, e.g., "Push Factors", Globalization 101, http://www.globalizationı1.org/push-factors/, (accessed 19 May 2014).

11 K. Hobér, Transforming East European Law, Uppsala, Iustus Förlag, 1997, p. 171.

12 D Hughes, "Trafficking for Sexual Exploitation: The Case of the Russian Federation", гом, 2002, p. 12.

13 See, e.g., "Victims of Trafficking: Who are they? A Statistical Profile for the Period of March 2006 - 15 November 2009", IOM, Us State Department et al., p. 13, http://www.no2slavery .ru/files/Statistic_FINAL_424_eng_fin.pdf, (accessed 19 May 2014). Among Russian women with secondary education some $22 \%$ had completed secondary education and $62 \%$ had unfinished secondary education while only $16 \%$ had less than nine years of education. Among those with post-secondary education, $24 \%$ had a college education.

14 "Krajowy Program Działań na Rzecz Kobiet - drugi etap wdrąźeniowy na lata 2003-2005", Warszawa, p. 19 .
} 
background..$^{15}$ One example is the Roma population that is usually economically worse off than the majority population. Most of the children abducted from Albania for the purpose of organized begging in Italy come from Roma communities. ${ }^{16}$ A study on the recruiting process of children trafficking victims from Romania indicates that children of Roma origin run a higher risk of being trafficked than ethnic Romanians, ${ }^{17}$ and similar results have been shown for other countries of origin.

Another group that has suffered especially greatly from exploitation in trafficking is the Russian-speaking minority of the Baltic countries, especially in Latvia. Apparently there are different possibilities or rather different circles in the Dantonian hell for trafficked women depending on their ethnicity. While women of Latvian ethnicity usually end up in brothels in Germany, Russianspeaking women residing in Latvia might find themselves in the most hellish of situations along the highways between major European cities or in the Balkans. ${ }^{18}$

With the advancement of technology, people living in the poorer regions of the world have been made even more aware of their own difficulties as well as exposed to the lifestyle of the 'rich'. ${ }^{19}$ Many people whose dreams have been inspired by the vivid pictures of relative wealth portrayed on soap operas and the like have left the region in hope of a better life which has led to a substantial loss of human capital in the countries of origin.

There also seems to be a connection between hard economic conditions and increased violence against women and children. A couple of years ago, domestic violence in Poland reached such proportions that a nationwide televised campaign with the telling slogan Dom to nie ring meaning $A$ home is not a boxing ring, was launched. According to some scholars, this development can

\footnotetext{
15 T. Obokota, 2006, p. 44.

16 "Trafficking in Children in South Eastern Europe: Situation Overview", Stability Pact for South Eastern Europe - Task Force on Trafficking in Human Beings, UNICEF, 2002, p. 1.

17 "Trafficking in Children in Romania - Study on the Recruiting Process", General Inspectorate of Romanian Police National Agency against Trafficking in Persons, Twinning Project PHARE Ro2006/IB/JH 08, 24 November 2009, p. 50 and G. Fusu-Plaiasu, I. Ionescu, and R. Iordache (eds.), Fra Thematic Study on Child Trafficking. Romania, European Union Agency for Fundamental Rights, p. 20.

18 Interview conducted by the author with A. Vaisla, Head of Unit 2, Drug Enforcement Bureau for Fight against Trafficking in Human Beings of the Organised Crime Combating Board of Main Criminal Police Board of State Police, Ministry of Interior, Latvia, on 11 May 2005 at 11:30 in Riga, Latvia.

19 D. Hughes, "Trafficking for Sexual Exploitation: The Case of the Russian Federation", IOM, 2002, p. 11 .
} 
partly be explained by the reintroduction of certain values that portray women either as wives or mothers or as sex objects, ${ }^{20}$ and partly by growing poverty and alcohol abuse.

According to some, trafficking is culturally constructed. Cultural values are, e.g., said to be a factor where the expectance of children to contribute to the family's economy is concerned. Children are sent to neighbouring cities and sometimes abroad to provide for the family and are expected to send home remittances. Thailand is mentioned as an example of a country where women and children are sometimes sold into prostitution as a means of contributing to the family's economy. ${ }^{21}$ Moreover, this also occurs in poor European countries such as Albania. ${ }^{22}$ There have also been incidents in both Poland and Russia of parents trying to sell their children. ${ }^{23}$ In many of these instances it is, however, important not to demonize the parents. These often see no other choice than to send their children abroad or to neighbouring cities in hope of them securing an income or simply surviving. Usually, whole families share the same fate. Even though there might have been instances of parents selling their children for selfish motives, a vast majority simply do it to survive.

In some places men, due to their responsibility as the breadwinners (also a cultural construction), are expected to go abroad in search of work if none is to be found at home. This is especially true in post-socialist states such as Moldova, Belarus, or Ukraine. ${ }^{24}$ In these countries the number of victims of forced labour is reported to be higher than the number of people trafficked for sexual exploitation.

Political and legal push factors can also influence the patterns of trafficking. Regional conflicts like those in the Balkans or Caucasus aggravate the situation

20 J.E. Johnson, "Violence against Women in Russia” in W.A. Pridemore (edt.), Ruling Russia. Law, Crime and Justice in a Changing Society, Lanham, Rowman \& Littlefield Publishers, 2005, p. 163 .

21 T. Obokata, 2006, p.44.

22 B. Scharlowski, S. Prata, "How Children are Exploited in Europe", International Foundation terre des homes, Eu Forum on Prevention of Organized Crime, Brussels, 2004, p. 5 .

23 In February 2012, a woman tried to sell her five-year old son for 300,000 Russian rubles to a policeman who was working undercover and posing as a potential buyer. Reportedly, she did not ask any questions and was only interested in receiving the money in order to be able to start her own company. See information posted by the Russian Ministry of Interior, "V Khabarovskom kraije zaderzhana zhenshchina, pytavshajasja prodat' svojego maloletnego rebenka", 28 February 2012, http://pda.mvd.ru/news/item/157635/, (accessed 19 May).

24 "Trafficking of Men - A Trend Less Considered", IOм Migration Research Series, no. 36, 2008. 
by fuelling political instability and thus economic regression. In the 1990s alone, nearly 3.6 million people died as a result of internal conflicts while 'only' 220,000 deaths were attributed to conflicts among states. Research indicates that civil conflicts tend to erupt as grave horizontal inequalities between groups (be they ethnic, religious, or social) become apparent.

The collapse of the Soviet Union has produced an identity crisis among the native Russians, ${ }^{25}$ which is one of the reasons behind the conflicts taking place in the Caucasus today. This identity crisis is illustrated by the preamble of the Russian constitution which speaks of Rossija (motherland) and Rossijskaja Federatsija (the power, the federation of states) and refers to some of its subjects as Russkij (ethnic Russians) and to others as Rossijskij (citizens of the Russian Federation).

Trafficking laws of many countries of origin are either non-existent or flawed or the implementation is poor. Corruption plays an important role as some officials are either directly or indirectly involved in the illegal trade. ${ }^{26}$ The combination of the element of organized crime, flawed laws, and poor law enforcement creates prospects for illegal migration to thrive. As an example, so-called employment agencies can be mentioned. Some of these enterprises organize trafficking behind seemingly legal facades. They advertise in the local press, arrange meetings between 'employers' and potential victims, and provide detailed information about the possibilities of employment abroad. At times, these organizations operate without proper licences. In 2003, Moldovan authorities estimated that more than two hundred employment firms were operating without legal permits, whereas only thirty-five agencies were authorized. ${ }^{27}$ At the same time, the interest to find work abroad was huge among the Moldovan population, with more than twenty thousand young women leaving Moldova every year. ${ }^{28}$

In addition to factors present in the countries of origin that influence the supply of victims, organized crime, etc., there are also factors in the countries of destinations that influence trafficking patterns. These so-called pull factors are usually described as antonyms to the push factors. Obviously, one of the main incentives to move abroad is to improve one's financial situation, so

25 A. Agadjanin, "Revising Pandora's Gifts: Religious and National Identity in the Post-Soviet Societal Fabric", Europe-Asia Studies, vol. 53, no. 3, 2001, p. 473.

26 D. Hughes, "The 'Natasha' Trade: The Transnational Shadow Market of Trafficking in Women", Journal of International Affairs, 2000, p. 9 .

27 T. El-Cherkeh et al., "EU-Enlargement, Migration and Trafficking in Women: The Case of South Eastern Europe", HWwA-Report 247, Hamburgisches Welt-Wirtschafts-Archiv (HWWA), Hamburg Institute of International Economics, 2004, p. 82. Ibid, p. 79 . 
countries with healthy economies and generous welfare systems might be prioritized, but there are also other factors that might entice people to migrate. Persons living in regions plagued by conflicts yearn for political stability. Some may be contemplating migration in order to escape discrimination, be it racial or based on gender. However, there are also additional factors which can affect a potential migrant's decision.

Just like language or cultural barriers between the country of origin and destination might make a person question the decision to migrate, the opposite might tip the scales in favour of a move. Geographic proximity as well as relatives or large diaspora communities living in the potential country of destination are also factors that are said to influence the migrants' decisions.

It should be borne in mind, however, that the demand for cheap illegal labour, sexual services, or organs for transplantation in the destination countries indirectly influences the trafficking process since traffickers will send the victims to where the demand for their services is the most substantial. Can we then argue that trafficking is both supply and demand driven? Some people may say that they would not buy a product if they knew that it was produced by exploited labour or that they would not solicit the services of a trafficked sex worker and that they by that logic do not demand trafficking. This might be true if we adopt a more narrow interpretation of the concept of demand. If, however, demand is seen in a broader context and arguably from a more logical point of view, it seems that our actions as consumers of both goods and services do have an impact on trafficking. For example, demand might encompass an employer's need for cheap labour, or a consumer's request for cheap goods and services. ${ }^{29}$ Having discussed the push and pull factors, it is now time to look at the ways in which trafficking can be addressed and at the various areas that the crime affects.

Trafficking can take many different forms and thus be seen from various perspectives. From the point of view of the victim, it is all about finding better living opportunities by means of migration. A state might see the very same action as a violation of its laws on migration, labour, etc. It might also see the people responsible for it, i.e., the criminal organization, as a security threat. International human rights organizations see trafficking not only as a crime but also as a violation of basic human rights. There are thus several stakeholders and perspectives in this area. In the following, the different ways of looking at trafficking will be addressed in more detail. We will start with the umbrella concept of migration.

29 "Is Trafficking in Human Beings Demand Driven?", A Multi-Country Pilot Study, no. 15, Iом Migration Research Series, Іом, 2003, pp. 9-10. 


\section{Trafficking from Various Perspectives}

\section{Trafficking from a Migration Perspective}

Migration is a common and essential characteristic of life. Throughout time, entire societies have been developed and destroyed as a result of movements of people. Nevertheless, the people migrating irregularly today are in vulnerable situations. Being under the radar of their host countries makes them especially susceptible to various forms of exploitation such as being trafficked.

People have been migrating in search for better life, work, or even refuge from wars or natural disasters for ages. In that sense, migration is not a new phenomenon. However, its flows have even during the last decades undergone some important changes. Although most people migrate within their own countries as a result of urbanization, some 200 million people are believed to have migrated internationally. ${ }^{30}$

There are several reasons why the migration of today differs from past movements. The first reason is its international nature, which is said to be the result of globalization. Globalization affects the way that people become aware of conditions existent in other countries as well as the way that people travel. It is also said to increase the number of possible countries of origin and destination. The circumstance that the number of migrants seems to be on the increase constitutes the second reason. The third reason is the differentiation of migration as in people of various ethnicities forming the migration flows. Migration has increasingly become a political issue as states see it as a potential risk to, e.g., their welfare systems or even, when irregular migration is considered, as a security issue. The securitization of migration thus forms the fourth reason while the fact that contemporary migration as a result of its alleged feminization is often addressed in terms of gender is the fifth reason. This last characteristic of modern migration will be addressed in more detail in the section below.

Global migration is usually divided into regular and irregular migration. The latter can be divided into smuggling and trafficking, though in reality the line between these two is often blurred. Irregular migration violates the migration laws of states. The practice takes on several forms, one being a family-organized form of illegal entry. A person may try to enter the relevant country on the basis of a valid document issued to a family member of similar appearance. Another way of gaining illegal entry to a country of destination is via smuggling. This is usually facilitated on a larger scale by organized crime groups. The smuggling of persons is perceived as a crime directed against the state, notably

“Human Development Report”, 2009, UNDP, p. 1. 
the state's right to control its own borders. The smuggled persons' consent to the offence often prevents the authorities from seeing and thus treating these persons as victims.

Although a person might consent to being smuggled and perhaps even initiate the transaction, the conditions under which the subsequent smuggling is carried out might differ greatly from the initial agreement. It is a well-known fact that people have been seriously injured or even killed during illegal and dangerous transports. Some persons, particularly those who have not been able to pay the smugglers upon departure but have promised to pay them back as soon as they start earning money in the new country, may fall victim to forced labour, sexual exploitation, or both. In such cases, it is difficult if not impossible to draw a clear line between trafficking and smuggling. ${ }^{31}$

The fact that smuggling circumvents national laws and governance systems and is often organized by international crime syndicates, poses a serious threat not only to individuals but also to states. This concerns both countries of origin where so-called brain drain and the general drain of workers might occur and countries of destination where illegal entities will attempt to circumvent, among other things, migration and labour laws of the relevant country.

One of the main forms of both regular and irregular migration is labourdriven. The possibility of finding jobs with better wages, combined with employers who are willing to hire irregular workers and consumers who are interested in cheaper products and services, constitutes a significant pull factor.

\section{Trafficking from a Gender Perspective}

Over the last three decades, the overall number of female migrants has been on the increase. Also, between the years 1965 and 1990, the number of women migrants in the most important, industrialized as well as developing, receiving countries actually grew faster than the number of their male counterparts. Today, female migrants constitute some $50 \%$ of all migrants. ${ }^{32}$ The real change of the last decades, however, relates to how women move. The majority of women now migrate independently, not as wives or daughters but as individuals in search of work opportunities. Moreover, some women migrate as primary breadwinners for their immediate or extended families. As a result of the increasing flows of women migrants, the concept of the feminization of migration has been coined.

\footnotetext{
31 J. Fitzpatrick, "Trafficking as a Human Rights Violation: The Complex Intersection of Legal Frameworks for Conceptualizing and Combating Trafficking", Michigan Journal of International Law, vol. 24, 2002-2003, p. 1150.

"Human Development Report", 2009, UNDP, p. 25.
} 
This concept breaks with the traditional migration theories where women migrants were mostly viewed as dependents following their husbands or male family members. As a result of (independent) migration being viewed as a distinctly male practice, the notion of women as individual migrants remains somewhat under-researched. Arguably, this has made an imprint on modern acts concerning irregular migration such as the Palermo Protocol on smuggling, ${ }^{33}$ which is said to have been created with an idea of a stereotypical male migrant in mind. While the stereotypical picture of an independent migrant is a male in search of work abroad, the stereotypical victim of trafficking is often portrayed as a docile, coerced young female.

However, the stereotypical ideal of the 'coerced innocent' is arguably "too simplistic to reflect the reality of the majority of known trafficking situations" 34 as most victims of both trafficking and smuggling make conscious decisions to migrate although their decisions may be based on fraudulent information. The aforementioned stereotypes may hinder some traditionally atypical victims from receiving the state assistance to which they are actually, at least morally, entitled.

What, if any, differences are there then between male and female migrants? Generally speaking, some uniting factors exist, but there are also considerable discrepancies. Both men and women may be tempted to migrate as a result of political instability or as a way of escaping from natural disaster. In the majority of cases, however, poor economic and social opportunities in the country of origin and, presumably, better opportunities in the relevant state of destination influence the migrants' decisions. Both sexes move in search of better work opportunities, to support family members, to find better living conditions, education opportunities for their children, etc.

The setting in which a person lives is also said to affect her potential to migrate. ${ }^{35}$ In some regions of the world, unmarried, single, or divorced women are stigmatized by their own communities. In the case of some women who are stuck in abusive relationships or are victims of domestic violence, migration becomes a way out of abuse. Arranged marriages are still a common practice in some places of the world, making a considerable number of women migrate for this purpose.

Protocol against the Smuggling of Migrants by Land, Sea and Air, supplementing the United Nations Convention against Transnational Organized Crime.

34 "Violence against and Trafficking in Women as Symptoms of Discrimination: The Potential of CEDAW as an Antidote", Gender and Development Discussion Paper Series, no. 17, Economic and Social Commission for Asia and the Pacific, December 2005, p. 7 
Although poor and yearning for a better life, some women may traditionally be forbidden to take the step to leave their communities, something that in effect restricts their freedom of movement. Also, in some instances women are not considered as valuable as their male family members. If a family has limited financial resources to invest, the lot to stay put will usually fall on women.

The abovementioned circumstance constitutes one of the differences between male and female migrants. In certain cases, however, it may work in the opposite direction, as some women might see the traditional constraints on their mobility as a reason to move to a less discriminatory society.

Men and women also show different vulnerability to human rights abuses in the countries of destination, e.g., varying forms of exploitation or specific health risks. While men as a group may be more exposed to labour-related injuries such as falling when working without a safety line on a construction site, as a result of the exploitation in the sex industry, female migrants are more likely to contract sexually transmitted diseases like HIV.

Consequently, migration is not a gender-neutral practice. From the very moment that a woman decides to leave her country of origin to the time when she first arrives in her country of choice, and usually even thereafter, her decisions, experiences, and vulnerabilities to a large extent differ from those of her male counterpart. We can see that poverty and poor development drives both regular and irregular migration, as it works as a push factor that forces people to migrate. Below, trafficking will be discussed in that particular context.

\section{Trafficking as a Result of Poverty, Development, and Education}

The roots of trafficking in human beings are to a large extent to be found in poverty. Human trafficking in turn perpetuates poverty, which creates a vicious circle. Victims of trafficking usually come from the lowest strata of society. The subsequent exploitation perpetuates that state by denying them basic rights, e.g., the right to health care, education, security, etc. ${ }^{36}$

By studying court judgments, we can see that tough economic conditions indeed constitute one of the main factors that influence people's decisions to try their luck abroad. Research from different countries indicates that a vast majority of victims of trafficking were unemployed in their countries of origin. This especially relates to women, whose chance of finding a job is less than

36 T. Truong, "Poverty, Gender and Human Trafficking in Sub-Saharan Africa: Rethinking Best Practices in Migration Management", UnESCO, 2006. 
that of men. ${ }^{37}$ As a result of the transition process, women were the first to lose their jobs. Moreover, as a result of the failure of social services, the main responsibility to care for the children and elderly and, in many instances, to provide for whole families, was put on women. ${ }^{38}$ This development made women migrate in a hitherto unprecedented way.

Domestic violence as well as gender and ethnic discrimination perpetuate poverty, thus contributing to trafficking in human beings. Many victims are members of various minorities such as the Roma minority in South-eastern Europe or come from rural areas or cities with high unemployment rates. The majority of victims also have a very poor education, little or no language skills, and little experience of traveling abroad.

Trafficking perpetuates poor development by means of brain drain as well as the discrimination of women and ethnic minorities. In addition to being a development issue, trafficking is also seen as a serious security threat. This perspective will be addressed in the following section.

\section{Trafficking as a Security Issue}

The international community considers some illegal acts to be of a rather serious nature, constituting threats against society and men alike. In the context of the EU, these are the serious offences referred to in Article 83(1) TFEU. ${ }^{39}$ According to the EU, organized crime takes a variety of forms: trafficking in human beings, drugs and firearms trafficking, money laundering, and the illegal shipment and dumping of waste inside and outside of Europe. ${ }^{40}$

Human trafficking is viewed not only as a serious crime against individuals but also as a form of organized crime that is often linked to other illegal

37 "Fattigdom och människohandel - En strategi för bekämpning av människohandel genom Sveriges internationella utvecklingssamarbete", Enheten för Global Utveckling, Stockholm, 2003, p. 13 .

38 "Trafficking in Human Beings in South-Eastern Europe", UNICEF, UNOHCHR, OsCE, 2004, p. 68.

39 Article 83(1) TFEU pertains to the regulation of substantive criminal law and states that the European Parliament and the Council may establish minimum rules with regard to the definition of criminal law offences and sanctions in the area of particularly serious transnational crime. The provision stipulates a list of crimes in which the EU shall have legislative competence including terrorism, trafficking in human beings, organized crime, and money laundering.

40 "The Eu Internal Security Strategy in Action: Five Steps towards a More Secure Europe", Communication from the Commission to the European Parliament and the Council, p. 4, http://eur-lex.europa.eu/LexUriServ/LexUriServ.do?uri=COM:2010:0673:FIN:EN:PDF, (accessed 19 May 2014). 
practices. Apart from various types of smuggling that can be carried out in tandem with trafficking, there is also money laundering, where the profits stemming from various crimes like trafficking in human beings may end up. The latter practice can potentially enable criminals to invest in legitimate businesses, to influence politics, and even to run for political office.

Victims of trafficking may be forced to commit crimes such as theft and benefit fraud. This too impacts negatively on the economies and laws of the states of destination. The low-risk and high-reward nature of human trafficking contributes to making the practice an important security issue for states. Whereas the profits from the crime are significant, on par with profits from the illegal trade in narcotics and firearms, the risk of detection is comparatively low. ${ }^{41}$

One way of countering the abovementioned development has been to enforce proper legislation. Another way is to focus on vulnerable groups in the countries of origin and destination by trying to integrate them into their local societies. While these groups are particularly vulnerable to discrimination and abuse, they are also as a result of that isolation more likely to get involved in illicit activities. The same applies to aliens without residence permits and asylum seekers. ${ }^{42}$ In addition to the fact that trafficking violates the migration and labour laws of the countries of destination, it is also a health threat to society. This threat is described in more detail below.

\section{Trafficking as a Health Issue}

Studies point to an increasing link between prostitution and HIV infection. ${ }^{43}$ Furthermore, the same factors that increase a person's risk of being trafficked are the same that increase her vulnerability to HIV. Human trafficking and HIV/AIDS are caused by various root problems ranging from poor education and development possibilities, various forms of socioeconomic inequalities and lacking respect for human rights, to poor health protection.

Where data exist, the prevalence of HIV infection has been shown to be disproportionately high among people trafficked for the purpose of sexual

41 "Fighting Trafficking in Human Beings - An Integrated Approach and Proposals for An Action Plan", p. 4, http://eur-lex.europa.eu/LexUriServ/LexUriServ.do?uri=COM:2005:051 4:FIN:EN:PDF, (accessed 19 May 2014).

"The Stockholm Programme - An Open and Secure Europe Serving the Citizen", European Council, p. 8, (2010/C 115/o1), http://eur-lex.europa.eu/LexUriServ/LexUriServ.do?uri=OJ: C:2010:115:0001:0038:en:PDF, (accessed 19 May 2014).

43 See, e.g., "Drugs and Hiv/AIDS in Southeast Asia", UnODC, Regional Project for Reducing HIV Vulnerability from Drug Abuse (AD/RAS/o2/G22), 2004, p. 42, http://www.aspacngo .org/Acrobat/drugReport/HIV_AIDS.pdf, (accessed 19 May 2014). 
exploitation. In this context, women are seen as especially vulnerable although young boys are also at risk. However, all victims of trafficking run a higher risk of being infected with HIV than other people. ${ }^{44}$

The very conditions in which forced prostitution takes place inevitably increase the risk of contracting sexually transmitted diseases like HIV. These are often marked by high numbers of clients, some of whom prefer unprotected sex, and poor hygiene, voluntary or forced use of narcotics, as well as inadequate health care for those already infected with sexually transmitted diseases.

Victims of other types of exploitation such as forced labour may also become exposed to unsafe practices which can increase the risk of contracting an HIV infection.

HIV/AIDS has received little attention in efforts to address trafficking in persons, and specific HIV/AIDS prevention and care services hardly exist for these people. General responses addressing HIV/AIDs have little impact on trafficked persons due to the clandestine nature of human trafficking, and because people who have been trafficked are not usually reached by services. ${ }^{45}$

In addition to all the factors mentioned above, trafficking in human beings is also a grave violation of basic human rights. Actually, all of the factors mentioned in the previous sections can be summed up as breaches of positive human rights such as the right to health care and education. However, trafficking also violates the most basic, so-called negative, human rights by treating people as slaves. Below, trafficking as a human rights issue is discussed in more detail.

\section{Trafficking as a Human Rights Issue}

The by far most reprehensible element of trafficking is its severe violation of the victims' human rights and basic democratic principles. Traffickers not only violate the human rights of individuals but also certain values essential to the fabric of liberal democracies such as the prohibition of slavery. It is also important to keep in mind that the violation is not committed by a state against an individual but by individuals toward their fellow citizens.

44 "ILO Action against Trafficking in Human Beings", ILO, 2008, p. 31, http://www.ilo.org/ wcmsp5/groups/public/@ed_norm/@declaration/documents/publication/wcms _090356.pdf, (accessed 19 May 2014). more-about-people-vulnerable-to-human-trafficking.html, (accessed 19 May 2014). 
Trafficking is both a cause and a consequence of the violation of human rights and is explicitly recognized as such by the international community. ${ }^{46}$ This was first officially acknowledged in the ECtHR judgment Siliadin vs. France. ${ }^{47}$ In this case, the court looked into the situation of a girl from Africa held in servitude as a housemaid in France. That judgment focused on the failing of the criminal law framework of the country of destination in place at the time. The Court stated the obligation of the state signatories to the ECHR to penalize and prosecute acts of slavery, servitude, and forced labour. It thus highlighted the requirement for states to enact proper legislation that prohibits trafficking and to honour their obligations as set out in Article 4 of the ECHR.

In a judgment from 2010 the Court extended its reasoning. The case concerned the death of Oxana Rantseva and was brought before the court by the victim's father. ${ }^{48}$ The woman was trafficked to Cyprus for the purpose of sexual exploitation. Within a few weeks she left her workplace but was traced by her employer who brought her to the police with the aim of having her detained and extradited as he wished to employ someone else. The police noted that the woman's stay in Cyprus was not illegal but nevertheless forced her to go back to her workplace with the trafficker. On that same night, the victim fell from a balcony to her death after trying to escape from her captor. Despite the peculiar circumstances of her death, the local police never investigated it as a possible case of human trafficking.

Whereas in Siliadin vs. France the Court focused on the state's obligation to penalise and prosecute trafficking, in Rantsevvs. Cyprus and Russia it also held that states have a positive obligation to prevent trafficking and to assist the victims of the crime. This means that not only are proper criminal provisions necessary, i.e., that individuals, so to speak, have a negative right not to get trafficked, but also that states must carry out preventive measures as well as offer victim protection. The latter implies that individuals also have positive enforceable rights in relation to states which in turn have a corresponding duty to protect these rights.

46 C. Rijken, E. de Volder, “The European Union's Struggle to Realize a Human Rights BasedApproach to Trafficking in Human Beings", Connecticut Journal of International Law, vol. 25, no. 49, 2009, p. 52. Report of the UN High Commissioner for Human Rights (UNHCHR), "Recommended Principles and Guidelines on Human Rights and Human Trafficking", 5, U.N. Doc. E/2002/68/add.1, May 2002.

47 Case of Siliadin vs. France, Application no 73316/o1, Judgment 27 July 2005.

48 Case of Rantsev vs. Cyprus and Russia, Application no. 25965/04, 2010, Judgment Strasbourg, 7 January 2010, final 10 May 2010. 
Negative rights or obligations have always been viewed as inherent in the ECHR. This does not, however, apply to the positive obligations. Although some of these are explicitly set out in the ECHR, the concept as such, and the enforcements mechanisms for these types of obligations, did not appear until the late 1960 s and the Belgian linguistic case ${ }^{49}$ From that point on, the ECtHR has continued to broaden this category of obligations. By the same token, the Court has strengthened the substantive requirements of the convention and connected them to procedural obligations which are independent of Articles 6 and 13 of the document.

While substantive obligations are drawn from specific provisions, procedural obligations are said to be drawn from these provisions in conjunction with Article 1 of the convention. ${ }^{50}$ Article 1 has thus become a keystone of the convention system. It is said to form an independent source of general positive obligations with regard to states. ${ }^{51}$ The motives of the Court have been to safeguard the rights of the individuals by guaranteeing them the effective enjoyment of positive rights. The nature of positive rights is such that states must take the necessary measures to safeguard these rights. These measures might be judicial, procedural, etc.

In Rantsev v. Cyprus and Russia, the Court also managed to incorporate other international instruments into its judgment, notably the Palermo Protocol. In this unanimous milestone judgment, the Court confirmed that trafficking cannot be considered consistent with the values of the ECHR, most notably Article 4 of the convention or with a democratic society. ${ }^{52}$ Although not explicitly mentioned in the convention, trafficking in human beings falls

49 Belgian Linguistics Case of 23 July 1968, 1 E HRR 252 as referred to in J.F. Akandji-Kombe, Positive Obligations under the European Convention on Human Rights. A Guide to the Implementation of the European Convention on Human Rights, Human rights handbooks no. 7 , p. 5 .

$50 \quad$ See, e.g., Case of Assenov and others v. Bulgaria, Application no. 9o/1997/874/1086, 28 October 1998, where Article 3 of the ECHR was applied in conjunction with Article 1.

51 See, e.g., Case of Assanidze v. Georgia, Application no. 71503/o1, 8 April 2004, where the court held that Article 1 requires states to implement a system that would guarantee the application of the ECHR over all its territory and in relation to every individual.

$5^{2}$ The court held: "[b]y its very nature and aim of exploitation [human trafficking] is based on the exercise of powers attaching to the right of ownership. It treats human beings as commodities to be bought and sold and put to forced labour, often for little or no payment, usually in the sex industry but also elsewhere...It implies close surveillance of the activities of victims, whose movements are often circumscribed... It involves the use of violence and threats against victims, who live and work under poor conditions..." 
within the ambit of Article 4 which absolutely prohibits slavery, servitude, and forced labour.

The Court also clarified the obligation of states, as it argued that national authorities that are aware of a situation of human trafficking or of the real risk that an individual might end up in such a situation are required to take appropriate measures. This includes a procedural obligation to investigate situations of potential human trafficking and to cooperate with other state parties. This applies to states of origin, transit, and destination.

In the abovementioned case, Cyprus was found to have violated Article 4 in multiple respects including the obligation to create an effective administrative framework to prevent trafficking in general and the obligation to take protective measures in the case of the victim in particular. Russia had failed to investigate the alleged violation's start in Russia, after the Russian authorities had become aware of the victim's case.

The Court also found that Cyprus had violated the victim's right to her liberty, first by illegally detaining her at the police station and later by forcing her to go back with her employer. The latter action was said to be a clear violation of Article 5 of the ECHR as a result of the authorities having failed to observe their positive obligation to protect the victim from arbitrary detention by a third party. In this particular case, they had actually contributed to her loss of liberty and subsequent death.

This passage is interesting in light of the fact that many countries still lack appropriate procedures when dealing with trafficking victims. Even if traffickers get convicted, the victims may still be detained or even deported without notice. It is not unusual that they are re-trafficked upon return. This not only poses a risk to the victims but also makes them less inclined to cooperate with the authorities.

Trafficking is a very serious crime where the victims are often treated in a violent manner. They are threatened, beaten, and drugged. It is also not uncommon for victims of trafficking to get infected with HIV or to become pregnant and then be forced to undergo abortions. There have even been anecdotal reports of executions of women who had tried to escape from the traffickers. The alleged executions were public in order to deter other women who might have been contemplating escape. Traffickers often threaten family members and friends of the victim who are still living in the home country. This is precisely what makes the crime so dangerous, its links to several states. While the exploitation takes place in a foreign country or a different region within a specific country, the recruiter remains in the country of origin or the local community where he can threaten remaining family members. The discussions on 
trafficking as a social practice presented in this chapter will form a backdrop against which the crime of trafficking will be discussed in the following. I will start with an analysis of the international definition of trafficking in its specific cultural and historical setting, namely previous and current international legislation in this area. 